\title{
Water relations and hydraulic architecture in Cerrado trees: adjustments to seasonal changes in water availability and evaporative demand
}

\author{
Sandra J. Bucci ${ }^{1,2 *}$, Fabian G. Scholz ${ }^{1,2}$, Guillermo Goldstein ${ }^{2,3,4}$, Frederick C. Meinzer ${ }^{5}$, Augusto \\ C. Franco ${ }^{6}$, Yongjiang Zhang ${ }^{4,7}$ and Guang-You $\mathbf{H a o}^{4,7}$
}

${ }^{1}$ Laboratorio de Ecología Funcional,Departamento de Biologia, Facultad de Ciencias Naturales, Universidad Nacional de la Patagonia San Juan Bosco, (9000) Comodoro Rivadavia, Argentina. ${ }^{2}$ Comisión Nacional de Investigaciones Científicas y Técnicas (CONICET), Argentina. ${ }^{3}$ Laboratorio de Ecología Funcional, Facultad de Ciencias Exactas y Naturales, Universidad de Buenos Aires, Ciudad Autónoma de Buenos Aires, Argentina. ${ }^{4}$ Department of Biology, University of Miami, P.O. Box 249118, Coral Gables, Florida 33124, USA. ${ }^{5}$ USDA Forest Service, Forestry Sciences Laboratory, 3200 SW Jefferson Way, Corvallis, Oregon 97331 USA. ${ }^{6}$ Departamento de Botanica, Universidade de Brasília, Caixa Postal 04457 Brasília, DF 70904-970 Brazil.'Xishuangbanna Tropical Botanical Garden, Chinese Academy of Sciences, 88 Xuefu Road, Kunming 650223, China. *Corresponding author: sj_bucci@unpata.edu.ar

Received: 8 September 2008; Accepted: 20 November 2008

We determined adjustments in physiology and morphology that allow Neotropical savanna trees from central Brazil (Cerrado) to avoid water deficits and to maintain a nearly constant internal water balance despite seasonal changes in precipitation and air saturation deficit (D). Precipitation in the study area is highly seasonal with about five nearly rainless months during which $\mathrm{D}$ is two fold higher compared to wet season values. As a consequence of the seasonal fluctuations in rainfall and $\mathrm{D}$, soil water potential changes substantially in the upper $100 \mathrm{~cm}$ of soil, but remains nearly constant below $2 \mathrm{~m}$ depth. Hydraulic architecture and water relations traits of Cerrado trees adjusted during the dry season to prevent increasing water deficits and insure homeostasis in minimum leaf water potential $\Psi_{\mathrm{L}}$ and in total daily water loss per plant (isohydry). The isohydric behavior of Cerrado trees was the result of a decrease in total leaf surface area per tree, a strong stomatal control of evaporative losses, an increase in leaf-specific hydraulic conductivity and leaf hydraulic conductance and an increase in the amount of water withdrawn from internal stem storage, during the dry season. Water transport efficiency increased in the same proportion in leaves and terminal stems during the dry season. All of these seasonal adjustments were important for maintaining $\Psi_{\mathrm{L}}$ above critical thresholds, which reduces the rate of embolism formation in stems and help to avoid turgor loss in leaf tissues still during the dry season. These adjustments allow the stems of most Cerrado woody species to operate far from the point of catastrophic dysfunction for cavitation, while leaves operate close to it and experience embolism on a daily basis, especially during the dry season.

Key words: isohydric behavior, hydraulic conductivity, soil water potential and water content, savanna, stomatal conductance, transpiration

Relações hídricas e arquitetura hidráulica em árvores do cerrado: adequação às variações sazonais de disponibilidade hídrica e de demanda evaporativa: O objetivo deste estudo foi determinar os ajustamentos na morfologia e fisiologia que permitem árvores das savanas neotropicais do Brasil Central (Cerrado) de evitar déficits hídricos e de manter um balanço hídrico interno praticamente constante apesar das variações sazonais da precipitação e no déficit de saturação do ar (D). A precipitação na área de estudo é fortemente sazonal, com cerca de cinco meses praticamente sem chuva durante os quais D é duas vezes maior aos valores medidos na época chuvosa. Como conseqüência da flutuação sazonal das chuvas e de D, o potencial hídrico do solo muda substancialmente, nos primeiros $100 \mathrm{~cm}$ do solo, mas permanece quase 
constante abaixo de $2 \mathrm{~m}$ de profundidade. A arquitetura hidráulica e os parâmetros relacionados a relações hídricas das árvores do Cerrado se ajustaram durante a estação seca para evitar o déficit hídrico crescente e assegurar a homeostase nos valores mínimos de potencial hídrico foliar $\Psi_{\mathrm{L}}$ e na perda total diária de água pela planta (iso-hidria). O comportamento iso-hídrico das árvores do Cerrado foi o resultado de uma diminuição da superfície foliar total por árvore, um forte controle estomático das perdas por evaporação, um aumento na condutividade hidráulica específica da folha e na condutância hidráulica foliar e um aumento da quantidade de águas retirada dos reservatórios internos do caule, durante a estação seca. A eficiência no transporte de água aumentou, nas mesmas proporções, nas folhas e nos ramos terminais durante a estação seca. Todos estes ajustamentos sazonais foram importantes para a manutenção de $\Psi_{\mathrm{L}}$ acima de limiares críticos, com isto contribuindo para uma redução na formação de embolismos nos ramos e ajudando a evitar a perda de turgor em tecidos foliares durante a época seca. Esses ajustes permitem que os ramos das espécies lenhosas do Cerrado operem bem distanciados do ponto de disfunção catastrófica para a cavitação, enquanto as folhas operam próximas e sofrem embolismos em uma base diária, especialmente durante a estação seca.

Palavras-chave: comportamento iso-hídrico, condutividade hidráulica, potencial hídrico do solo e conteúdo de água, savana, condutância estomática, transpiração

\section{INTRODUCTION}

Trees growing in tropical environments characterized by distinct wet and dry seasons have to seasonally adjust their morpho-physiological traits to cope successfully with changes in soil water availability. Intuitively the most obvious responses of a plant to cope with limited water availability in a strong seasonal environment would be a reduction in transpiration by stomatal limitation and/or dropping the leaves to further decrease evaporative water loss during the dry season. Many tree species growing in tropical dry forests are deciduous, dropping their leaves at the beginning of the dry season and producing a new crop of leaves at the beginning of the wet season (Borchert, 1994; Rivera et al., 2002). Their seasonal growth rates are well coupled to the seasonal changes in the availability of the main limiting resource: water. In contrast, physiological activity and growth rates of savanna trees are uncoupled from seasonal changes in precipitation (Gouveia, 1998; Meinzer et al., 1999; Prado et al., 2004; Simioni et al., 2004; Damascos et al., 2005; Bucci et al., 2005; Franco et al., 2005; Hoffmann et al., 2005), even though the seasonal pattern of precipitation is similar to that of dry forests. Indeed, seasonally deciduous or semideciduous forests occur throughout the savanna region in Central Brazil on rich Ca and Mg soils (Ratter et al., 1978).

The climate of savanna ecosystems of Central Brazil (Cerrado) is characterized by five months with very few rainfall events and a long period with high precipitations. Evaporative demand is substantially higher during the dry season (May to September) because of lower ambient relative humidity. The combination of higher evaporative demand and low precipitation during the dry season makes the Cerrado a potentially stressful environment for vascular plants. Despite stressful conditions during the rainless season, many tree species maintain an active crop of leaves during this period and new leaves are produced before the beginning of the wet season (Franco et al., 2005; Lenza and Klink, 2006). Stem growth rates increase after the first large rainfall pulses of the wet season and high growth rates are maintained until two to three months before the end of the wet season in early March (Saraceno, 2006). It is likely that photoassimilates, at this point in time, are channeled to enhance root growth, instead of stem growth, to insure water uptake during the dry season. The production of new leaves by savanna trees during the most unfavorable period for growth may be an adaptive response to the low nutrient availability in the soil (Sarmiento et al., 1985). The presence of completely expanded leaves before the first rainfall events can help to reduce nutrient leaching from leaves because their cuticle would be fully developed, making them less leachable compared to expanding leaves. Minimizing nutrient losses and at the same time decreasing leaf losses to herbivores, which are less active at the end of the dry season (Marquis et al., 2002), is advantageous in terms of nutrient and carbon balance. Nevertheless, maintaining leaves as well as producing new leaves during the dry season incurs a carbon cost for savanna trees. They have to cope with 
the higher cost of maintaining long and deep roots to tap water from abundant and more stable water sources available at depth (Scholz et al., 2008a). Even though most Cerrado trees have more than $50 \%$ of their biomass belowground (Sarmiento, 1983; Castro and Kauffman, 1998), some Cerrado woody species have relatively shallow root systems (Scholz et al., 2008a).

To avoid losing leaves during the unfavorable growth period, species from other seasonal ecosystems undergo osmotic adjustment in their photosynthetic and other metabolically active tissues to avoid losing cell turgor when water is depleted in the soil and plant water potential becomes more negative. Other changes in leafwater relations characteristics may include a decrease in the modulus of elasticity (Turner and Jones, 1980). However, if woody Cerrado species are isohydric (Franco, 1998; Meinzer et al., 1999; Prado et al., 2004; Bucci et al., 2005), then osmotic adjustment or any other change in pressure volume relationships in leaves during the dry season may not be needed. Different types of physiological and morphological adjustments that allow the trees to maintain leaf water potentials $\left(\Psi_{\mathrm{L}}\right)$ above the turgor loss point during the dry season are possible. The first objective of this study was to asses if dominant Cerrado woody species are isohydric, meaning that they maintain similar minimum $\Psi_{\mathrm{L}}$ throughout the year (Tardieu and Simonneau, 1998). The term isohydry is used interchangeably with homeostasis in minimum $\Psi_{\mathrm{L}}$ in this study. The second objective was to discuss the current knowledge and new data concerning physiological and morphological adjustments which favor the water balance of Cerrado woody species during the dry season. The third objective was to assess the degree of coordination between stem and leaf hydraulics to help identify additional mechanisms governing the regulation of internal water balance of savanna trees.

\section{MATERIAL AND METHODS}

Study site and plant material: The study was conducted in savanna sites with intermediate tree density (cerrado sensu stricto) at the Instituto Brasileiro de Geografia e Estatística (IBGE) Ecological Reserve, a field experimental

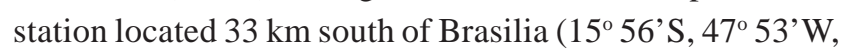
altitude $1100 \mathrm{~m}$ ). Annual precipitation in the reserve ranges from 880 to $2150 \mathrm{~mm}$ depending on the year with a mean of approximately $1500 \mathrm{~mm}$ (www.recor.org.br). There is a pronounced dry season from May through September with the months of June, July and August being nearly rainless. Mean monthly temperature ranges from 19 to $23^{\circ} \mathrm{C}$ with diurnal temperature variations of $20^{\circ} \mathrm{C}$ being common during the dry season. The soils are deep oxisols containing about $70 \%$ clay. The development of micro aggregate structures (e.g. cementation by iron oxides) allows Cerrado soils to be generally porous and well drained despite their high clay content (Furley and Ratter, 1988).

An extensive data set collected over 10 years (1996 to 2006) from 12 dominant woody species ranging from evergreen to brevideciduous and deciduous (Meinzer et al., 1999; Bucci et al., 2004a,b; Bucci et al., 2005; Bucci et al., 2006; Scholz et al., 2006; Scholz et al., 2007; Bucci et al., 2008; Goldstein et al., 2008; Hao et al., 2008; Scholz et al., 2008a,b) was used in this study in addition to previously unpublished data. The species studied, their family, leaf phenology and measured morphological and physiological variables in each species are listed in Table 1.

Soil water potential and volumetric water content: Soil water potential was measured using soil psychrometers (PST-55, Wescor, Logan, UT) which were deployed at $0.20,0.30,0.60$ and $1.00 \mathrm{~m}$ below the soil surface. The psychrometers were connected to a data logger (CR-7, Campbell Scientific, Logan, Utah, USA). Soil volumetric water content was measured with highly sensitive probes containing eight annular capacitance sensors (Sentek PTY LTD, Adelaide, Australia) positioned at several depths down to $250 \mathrm{~cm}$. Technical details for both methods are described in Bucci et al. (2008).

Leaf area index: Leaf area index of woody species was estimated with a LAI 2000 Plant Canopy Analyzer (LICOR Inc., Lincoln, Nebraska, USA) during wet (October, February and April) and dry (May, June and August) seasons as described previously (Hoffmann et al., 2005; Bucci et al., 2008).

Sapwood and leaf water potential, and turgor loss point: Sapwood water potential $\left(\Psi_{-\mathrm{sw}}\right)$ was measured in one representative tree per species during the dry season with in situ stem psychrometers (Plant Water Status Instruments, Guelph, Ontario, Canada) and recorded with a datalogger (CR-7, Campbell Scientific, Logan, UT, USA) at 10-min intervals as described in Scholz et al. (2007). 
Table 1. Species studied and family, leaf phenology and measured variables in each species.

\begin{tabular}{|c|c|c|}
\hline Species & Phenology & Variables \\
\hline $\begin{array}{l}\text { Byrsonima crassa Nied. } \\
\text { (Malphigiaceae) }\end{array}$ & Brevideciduous & $\mathrm{K}_{\text {Leaf }}, \mathrm{K}_{\mathrm{L}}, \mathrm{Lp}, \mathrm{A}_{\mathrm{L}}: \mathrm{A}_{\mathrm{S}}, \mathrm{E}, \Psi_{\mathrm{L}}, \Psi_{\text {sw }}, \mathrm{P}_{\text {stem; }}^{50} \mathrm{P}_{\text {leaf; }}^{50} \mathrm{~g}_{\mathrm{s}}, \pi^{0}$ \\
\hline $\begin{array}{l}\text { Blepharocalyx salicifolius (H.B.K.) } \\
\text { Berg (Myrtaceae) }\end{array}$ & Brevideciduous & $\mathrm{K}_{\mathrm{Leaf}}, \mathrm{K}_{\mathrm{L}}, \mathrm{Lp}, \mathrm{A}_{\mathrm{L}}: \mathrm{A}_{\mathrm{S}}, \mathrm{E}, \Psi_{\mathrm{L}}, \Psi_{\text {sw }}, \mathrm{P}_{\text {stem; }}^{50} \mathrm{P}_{\text {leaf; }}^{50} \mathrm{~g}_{\mathrm{s}}, \pi^{0}$, wS \\
\hline $\begin{array}{l}\text { Caryocar brasiliense Camb. } \\
\text { (Caryocaraceae) }\end{array}$ & Brevideciduous & $\mathrm{K}_{\mathrm{L}}, \mathrm{A}_{\mathrm{L}}: \mathrm{A}_{\mathrm{S}}, \mathrm{E}, \Psi_{\mathrm{L}}, \mathrm{g}, \pi^{0}, \mathrm{wS}$ \\
\hline $\begin{array}{l}\text { Erythroxylum suberosum St. Hil } \\
\text { (Erythroxylaceae) }\end{array}$ & Brevideciduous & $\mathrm{K}_{\mathrm{L}}, \mathrm{A}_{\mathrm{L}}: \mathrm{A}_{\mathrm{S}}, \mathrm{E}, \Psi_{\mathrm{L}}, \mathrm{g}_{\mathrm{s}}$ \\
\hline $\begin{array}{l}\text { Kielmeyera coriacea (Spr.) Mart } \\
\text { (Clusiaceae) }\end{array}$ & Deciduous & $\mathrm{K}_{\text {Leaf }}, \mathrm{K}_{\mathrm{L}}, \mathrm{Lp}, \mathrm{A}_{\mathrm{L}}: \mathrm{A}_{\mathrm{S}}, \mathrm{E}, \Psi_{\mathrm{L}}, \Psi_{\text {sw }}, \mathrm{P}_{\text {stem; }}^{50} \mathrm{P}_{\text {leaf; }}^{50} \mathrm{~g}_{\mathrm{s}}, \pi^{0}$, wS \\
\hline $\begin{array}{l}\text { Ouratea hexasperma Baill } \\
\text { (Ochnaceae) }\end{array}$ & Evergreen & $\mathrm{K}_{\mathrm{L}}, \mathrm{A}_{\mathrm{L}}: \mathrm{A}_{\mathrm{S}}, \mathrm{E}, \Psi_{\mathrm{L}}, \mathrm{g}_{\mathrm{s}}, \pi^{0}$ \\
\hline $\begin{array}{l}\text { Qualea parviflora Mart. } \\
\text { (Vochysiaceae) }\end{array}$ & Deciduous & $\mathrm{K}_{\text {Leaf }}, \mathrm{K}_{\mathrm{L}}, \mathrm{Lp}, \mathrm{K}_{\mathrm{L}}, \mathrm{A}_{\mathrm{L}}: \mathrm{A}_{\mathrm{S}}, \mathrm{E}, \Psi_{\mathrm{L}}, \Psi_{\text {sw }}, \mathrm{P}_{\text {stem; }}^{50} \mathrm{P}_{\text {leaf; }}^{50} \mathrm{~g}_{\mathrm{s}}, \pi^{0}$ \\
\hline $\begin{array}{l}\text { Roupala montana Aubl. } \\
\text { (Proteaceae) }\end{array}$ & Evergreen & $\Psi_{L}, g_{S}$ \\
\hline $\begin{array}{l}\text { Schefflera macrocarpa Seem D.C. } \\
\text { Frodin (Araliaceae) }\end{array}$ & Evergreen & $\mathrm{K}_{\mathrm{L}}, \mathrm{A}_{\mathrm{L}}: \mathrm{A}_{\mathrm{S}}, \mathrm{E}, \Psi_{\mathrm{L}}, \mathrm{g}_{\mathrm{S}}, \pi^{0}, \mathrm{wS}$ \\
\hline $\begin{array}{l}\text { Sclerolobium paniculatum Vog. } \\
\text { (Leguminosae) }\end{array}$ & Evergreen & $\Psi_{L}, \Psi_{\text {sw }} g_{s}, \pi^{0}, w s$ \\
\hline $\begin{array}{l}\text { Styrax ferrugineus Nees \& Mart. } \\
\text { (Styracaceae) }\end{array}$ & Evergreen & $\mathrm{K}_{\mathrm{L}}, \mathrm{A}_{\mathrm{L}}: \mathrm{A}_{\mathrm{S}}, \mathrm{E}, \Psi_{\mathrm{L}}, \Psi_{\mathrm{sw}}, \mathrm{P}_{\text {stem; }}^{50} \mathrm{P}_{\text {leaf; }}^{50} \mathrm{~g}_{\mathrm{s}}, \pi^{0}$ \\
\hline $\begin{array}{l}\text { Vochysia thyrsoidea Mart. } \\
\text { (Vochysiaceae) }\end{array}$ & Evergreen & $\mathrm{K}_{\mathrm{L}}, \mathrm{A}_{\mathrm{L}}: \mathrm{A}_{\mathrm{S}}, \mathrm{E}, \Psi_{\mathrm{L}}, \mathrm{g}_{\mathrm{s}}, \pi^{0}, \mathrm{wS}$ \\
\hline
\end{tabular}

Minimum leaf water potential $\left(\Psi_{\mathrm{L}}\right)$ was measured with a pressure chamber (PMS Instruments, Corvallis OR, USA) in three exposed leaves on each of three to five individuals per species during the dry season (AugustSetember) and wet season (February-March). The bulk leaf turgor loss point $\left(\pi^{0}\right)$ was determined from pressurevolume relationships (Tyree and Hammel, 1972) for three, fully developed exposed leaves from three individuals per species during the dry and wet seasons.

Root and leaf hydraulic properties and stomatal conductance: Total hydraulic conductivity (Lp) was measured in roots of $B$. crassa, B. salicifolius, $K$. coriaceae and Q. parviflora collected between 0530 and 0700 h in January (wet season) and August (dry season) as described in Scholz et al., (2008a). The Lp ( $\left.\mathrm{m} \mathrm{s}^{-1} \mathrm{MPa}^{-1}\right)$ was calculated as $\mathrm{Lp}=\left(\Delta \mathrm{Q}_{\mathrm{v}} / \Delta \mathrm{P}\right)(1 / \mathrm{A})$ where $\mathrm{Q}_{\mathrm{v}}\left(\mathrm{m}^{3} \mathrm{~s}^{-1}\right)$ is volumetric flow rate, $\mathrm{P}(\mathrm{MPa})$ is the pressure applied, and A $\left(\mathrm{m}^{2}\right)$ is the lateral surface area of the root segment (Nobel, Schulte and North, 1990).

Leaf-specific hydraulic conductivity $\left(\mathrm{K}_{\mathrm{L}} ; \mathrm{kg} \mathrm{m}^{-1} \mathrm{~s}^{-1}\right.$
$\mathrm{MPa}^{-1}$ ) was measured in three branches excised before dawn from three to five individuals per species during dry and wet seasons according to Bucci et al., (2004a) and Bucci et al., (2006). Branches were immediately re-cut under water and attached to a hydraulic conductivity apparatus (Tyree and Sperry, 1989). Leaf-specific conductivity was calculated as the mass flow rate divided by the pressure gradient across the branch segment and normalized by the total leaf area distal to the stem. Stem vulnerability curves, to estimate the pressure at 50 percent of loss conductivity ( $\mathrm{P}_{\text {stem }}^{50}$ ), were determined by measuring percentage loss of hydraulic conductivity due to embolism over a range of water potential reached during dehydration by the bench drying method (Sperry et al., 1988). Details about stem vulnerability curves are described in Bucci et al., (2006) and Hao et al., (2008).

Leaf hydraulic vulnerability curves were determined measuring leaf hydraulic conductance $\left(\mathrm{K}_{\text {Leaf }}\right)$ following the partial rehydration method described by Brodribb and Holbrook, (2003). Three leaves of five different trees per species were used to measure $K_{\text {Leaf }}$ and to estimate the 
pressure at 50 percent of loss conductivity $\left(\mathrm{P}_{\text {leaf }}^{50}\right)$. Capacitance values both before and after turgor loss point $\left(\pi^{0}\right)$ were calculated from leaf pressure-volume relations as described in Hao et al., (2008).

A steady state porometer (model LI-1600, LI-COR Inc., Lincoln, Nebraska, USA) was used to measure stomatal conductance $\left(\mathrm{g}_{\mathrm{s}}\right)$ of three to seven leaves on the same trees used to measure $\Psi_{\mathrm{L}}$, every 2 to $3 \mathrm{~h}$ during one day of dry and wet season and the maximum values as taken for this study. New, fully expanded leaves from sun-exposed areas of the crown were used for measurements.

Transpiration and stem water storage: The heat dissipation method (Granier, 1985, 1987) was used to measure the mass flow of water in ten out of the 12 species (three to five individuals per species) during two to five consecutive days at the end of the dry season (August and September) and at the peak of the wet season (January and February). Transpiration per unit leaf area (E) was obtained by dividing the mass flow of sap measured near the base of the main stem of each tree by the total leaf area per plant according to Meinzer et al., (1999) and Bucci et al., (2005). Total leaf area per plant was obtained by multiplying the number of leaves per plant by the average projected area per leaf, determined from a sub-sample of 10-50 leaves per plant.

To determine daily utilization of stored water for transpiration, sap flow was measured simultaneously in terminal branches and near the base of the main stem in six of study species as described in Scholz et al., (2008b). Stem water storage (ws) calculations were based on the method described by Goldstein et al., (1998).

\section{RESULTS}

Precipitation in the study area is highly seasonal with about five nearly rainless months (May through September, Figure 1). Mean daily air saturation deficit (D) is twice as great toward the end of the dry season compared to wet season values. As a consequence of the seasonal fluctuations in precipitation and $\mathrm{D}$, soil water potential fluctuated substantially in the upper $100 \mathrm{~cm}$ of soil. Average soil water potential, between 20 and $100 \mathrm{~cm}$ depth, ranged from $0 \mathrm{MPa}$ in the rainy season to about 2.0 MPa near the end of the dry season (Figure 2a). Soil water storage (the total amount of water in the upper 250 $\mathrm{cm}$ of the soil profile excluding the first $10 \mathrm{~cm}$ ) also changed seasonally. It decreased from about $400 \mathrm{~mm}$ in the wet season to about $230 \mathrm{~mm}$ at the peak of the dry season (Figure 2b). This would imply that the vegetation had used about $170 \mathrm{~mm}$ of water up to the peak of the dry season if one assumes that the period was rainless, and that there was neither lateral flow nor deep percolation. Tree and shrub leaf area index responded to changes in soil water availability decreasing from $1.4 \mathrm{~m}^{2} \mathrm{~m}^{-2}$ in the wet season to about $1 \mathrm{~m}^{2} \mathrm{~m}^{-2}$ at the peak of the dry season.

Several scaling relationships between leaf functional traits or between leaf traits and branch architectural traits across species were identified. In some cases only one mathematical function was enough to describe scaling relationships for both wet and dry season data, and in other cases two functions were used to describe dry and wet season relationships. Observed minimum $\Psi_{L}$ increased linearly with increasing $\pi^{0}$, across species (Figure 3). Minimum $\Psi_{\mathrm{L}}$ and $\pi^{0}$ did not differ between seasons and consequently only one functional relationship was fitted to all data. Leaves of all species were able to maintain positive turgor pressure still during the dry season, with the exception of $O$. hexasperma that reached the turgor loss point during the wet season. The observed minimum $\Psi_{\mathrm{L}}$ and $\pi^{0}$ relationship slope (0.90) did

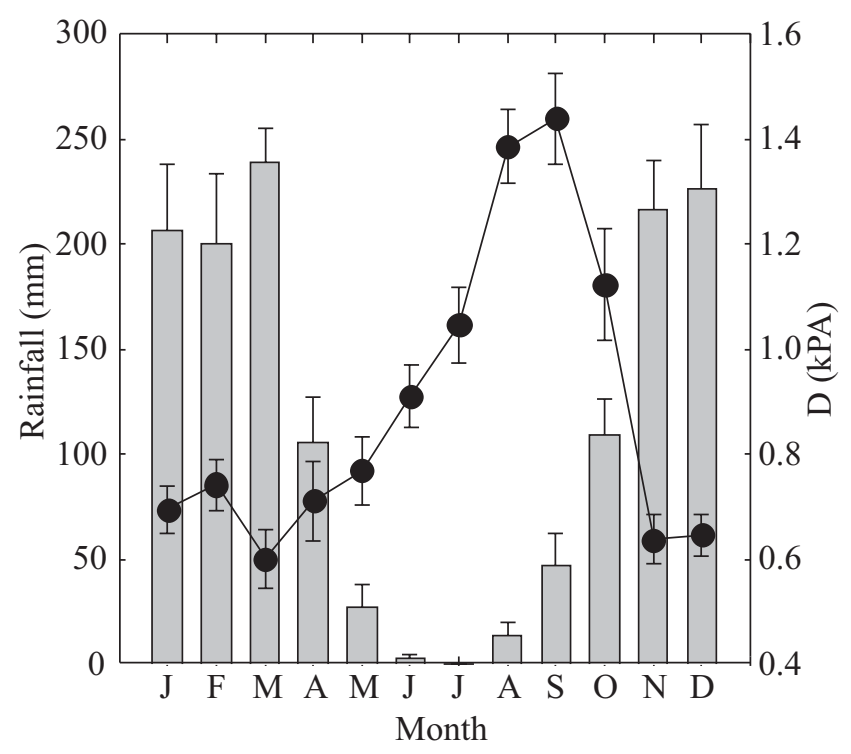

Figure 1. Ten-year monthly average (from 1995 to 2005) precipitation, and air saturation deficits (D), at the IBGE research station near Brasilia, Brazil. Bars are total monthly precipitation and the continuous line is D. Error bars are standard errors. Source: www.recor.org.br. 


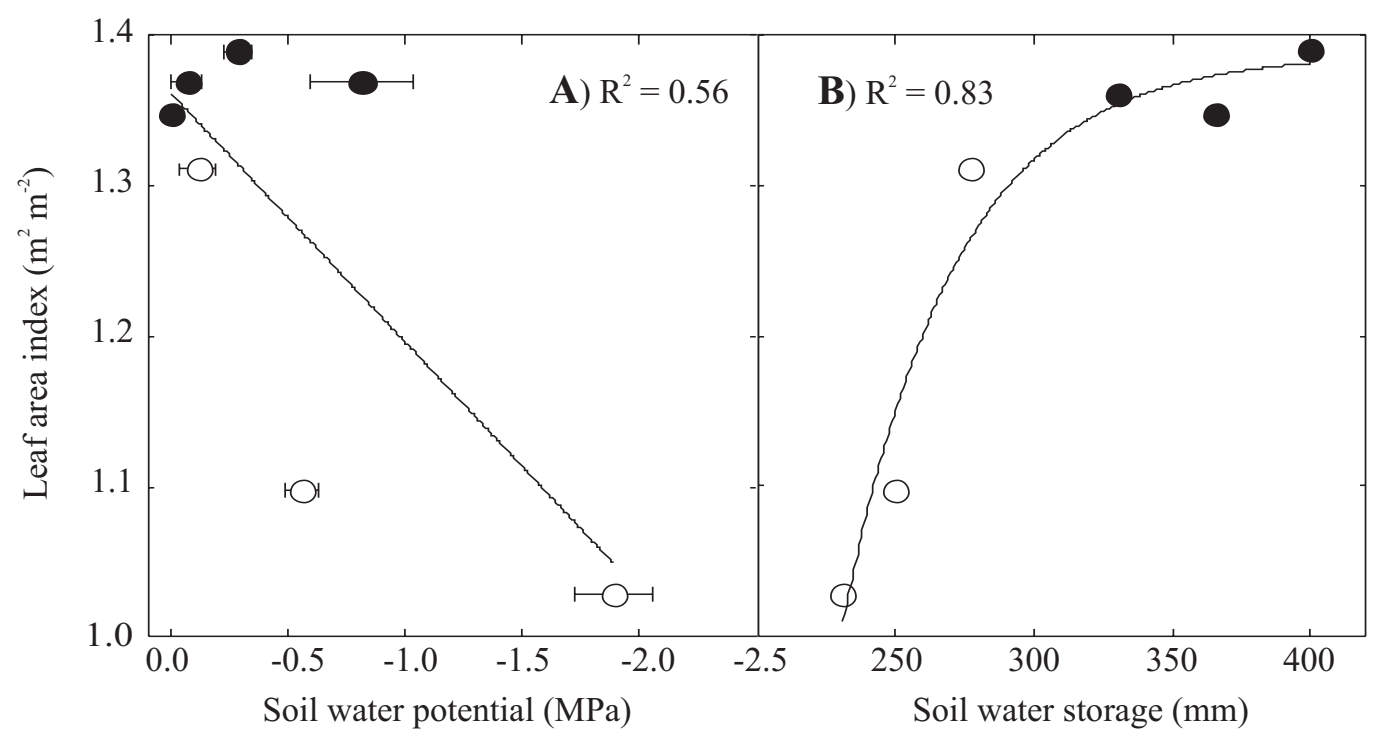

Figure 2. Leaf area index as a function of average soil water potential between 20 and $100 \mathrm{~cm}$ depth (a) and soil water storage between 10 and $250 \mathrm{~cm}$ depth (b) in a Cerrado site with intermediate tree density. Data points are leaf area index and soil water storage or soil water potential measured during the course of one year, encompassing wet (February and April) and dry (May, June and August) season periods. The line in (a) is the linear regression fitted to the data ( $\mathrm{y}=-4.83$ $+3.37 \mathrm{x} ; \mathrm{P}=0.05)$. The line in (b) is an exponential rise to a maximum fitted to the data $\left(\mathrm{y}=1.75^{*}(1-\exp (-0.004 \mathrm{x})) ; \mathrm{P}<0.05\right)$. Open symbols: dry season and closed symbols: wet season.

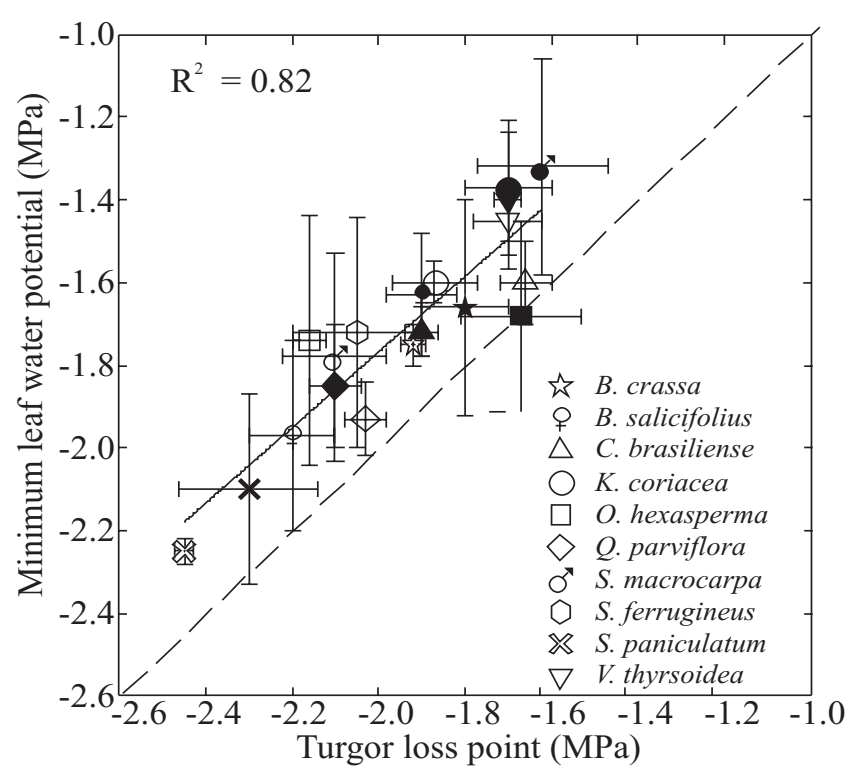

Figure 3. Minimum leaf water potential $\left(\Psi_{L}\right)$ as a function of the osmotic potential at the turgor loss point $\left(\pi^{0}\right)$ obtained during the wet season (filled symbols) and the dry season (open symbols) for ten dominant woody species. The continuous line is a linear regression fitted to both wet and dry seasons data $(\mathrm{y}=-0.40+0.90 \mathrm{x} ; \mathrm{P}<0.001)$. Dashed line is the $1: 1$ relationship between $\Psi_{\mathrm{L}}$ and $\pi^{0}$. Values are means \pm $\mathrm{SE}$ of three to five individuals per species. not differ significantly from 1 indicating that turgor pressure at minimum $\Psi_{\mathrm{L}}$ was more or less constant across species and seasons. Midday $\Psi_{L}$ increased with increasing maximum stomatal conductance measured at mid-morning; however linear relationships were fitted separately for wet and dry season data (Figure 4). Even though there were not species-specific differences in midday $\Psi_{\mathrm{L}}$ between seasons, stomatal conductance tended to be several fold lower in the dry season compared to the wet season $(\mathrm{P}<0.001)$.

Observed minimum $\Psi_{L}$ was less negative with increasing water used from internal stem water storage across species (Figure 5). Utilization of stored water was about $10 \%$ greater during the dry season compared to the wet season. Although the slopes of the relationships between minimum $\Psi_{\mathrm{L}}$ and stored water utilization were similar, the y-intercepts were significantly different $(\mathrm{P}<$ 0.005).

Transpiration per unit leaf surface area increased with increasing $\mathrm{K}_{\mathrm{L}}$ (Figure 6). Transpiration and $\mathrm{K}_{\mathrm{L}}$ were higher during the dry season compared to the wet season values for each species studied. A single functional relationship describing variation in transpiration and $\mathrm{K}_{\mathrm{L}}$ 


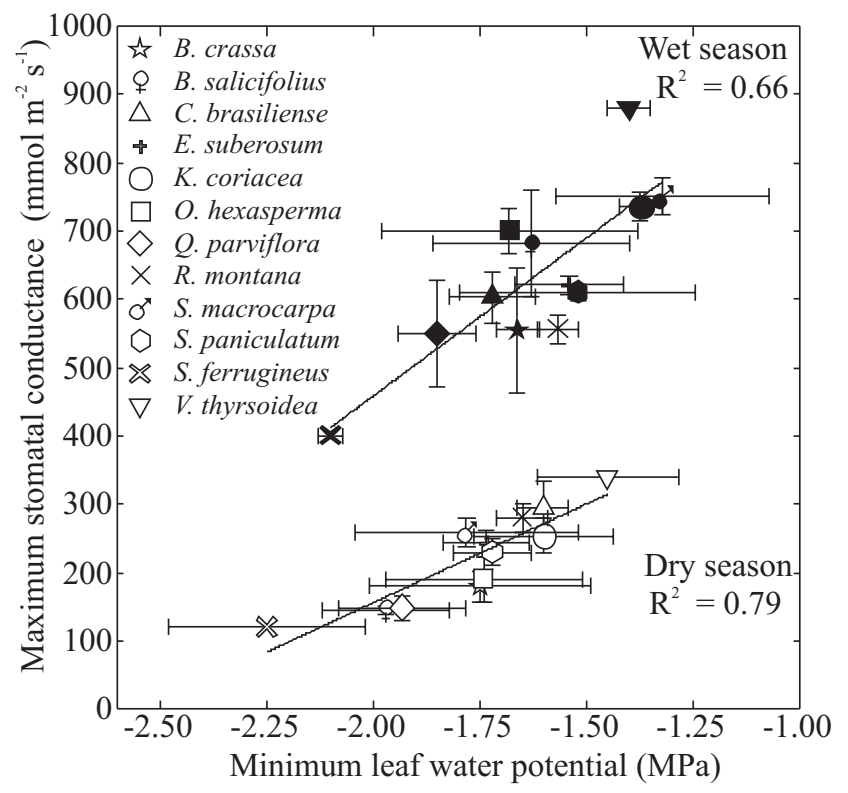

Figure 4. Maximum stomatal conductance of 12 dominant woody species as a function of observed minimum leaf water potential measured during the end of the dry season (August-September) and the peak of the wet season (January-February). Symbols for the dry season and wet season measurements are open and filled, respectively. Lines are linear regressions fitted to either the dry ( $\mathrm{y}=$ $734+289 x ; \mathrm{P}<0.001)$ or the wet season $(y=1383+462 x$; $P$ $<0.005)$ data.

was fitted to all species during both the dry and wet seasons. Leaf specific conductivity declined sharply with increasing $A_{L}: A_{S}$, a tree architectural index of potential constraints on water supply in relation to transpirational demand, across all species (Figure 7). Values measured in wet and dry seasons were included in the same relationship because $K_{L}$ were lower and $A_{L}$ : $A_{S}$ higher for each species during the wet season compared to the dry season. Lower $A_{L}$ : $A_{S}$ during the dry season was the result of a decrease in total leaf surface area per tree rather than changes in the cross sectional area of active stem xylem tissue.

Leaf hydraulic conductance $\left(\mathrm{K}_{\text {Leaf }}\right)$ was higher and total root hydraulic conductivity ( $\mathrm{Lp}$ ) was lower during the dry season, compared to wet season values, in four dominant Cerrado species (Figure 8). The differences between dry and wet season values were significant in all four species for $K_{\text {Leaf }}$, but for only 2 species for Lp. A single linear relationship adequately described the relationship between $\mathrm{K}_{\mathrm{L}}$ and $\mathrm{K}_{\text {Leaf }}$ using results from both

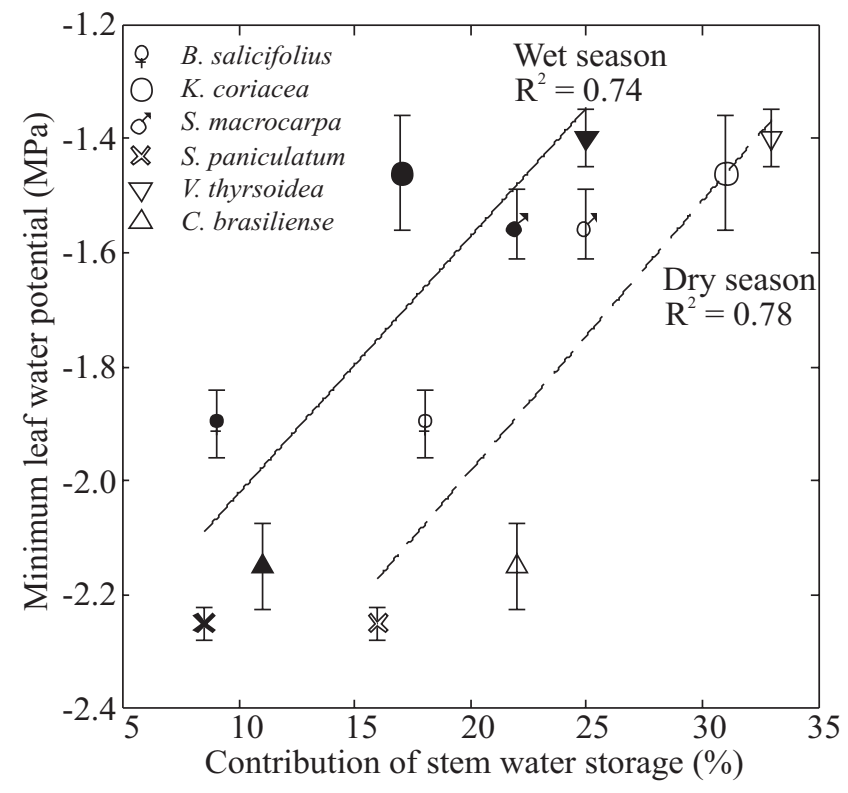

Figure 5. Minimum leaf water potential in relation to the contribution of stem water storage to total daily water use for six dominant woody species during the wet season (filled symbols) and the dry season (open symbols). The lines are linear regressions fitted to either the wet season (continuous line, $\mathrm{y}=-2.47+0.04 \mathrm{x} ; \mathrm{P}<0.05$ ) or dry season (dashed line; $\mathrm{y}=-2.9+0.05 \mathrm{x} ; \mathrm{P}<0.05$ ) data.

dry and wet seasons for all four species (Figure 9). Within species, the minimum sapwood water potential $\left(\Psi_{\mathrm{sw}}\right)$ was on average $1.2 \mathrm{MPa}$ more positive than the minimum $\Psi_{\mathrm{L}}$ (Table 2). Leaves of Cerrado tree species were more vulnerable to cavitation than their terminal stems, because the water potentials at $50 \%$ loss of maximum stem hydraulic conductivity $\left(\mathrm{P}_{\text {stem }}^{50}\right)$ were more negative than $\Psi_{L}$ at $50 \%$ loss of maximum leaf hydraulic conductance $\left(\mathrm{P}_{\text {leaf }}^{50}\right)$. On average, minimum $\Psi_{\mathrm{L}}$ was 0.6 MPa more negative than $\mathrm{P}^{50}$ leaf , whereas minimum $\Psi_{\text {sw }}$ was about $1.6 \mathrm{MPa}$ more positive than $\mathrm{P}^{50}$ stem .

\section{DISCUSSION}

Vascular plants differ substantially in their ability to regulate water loss to minimize seasonal fluctuations in tissue water status. The terms "isohydric" and "anisohydric" are used to divide the continuum of potential plant responses to seasonal changes in water availability and/or atmospheric evaporative demand in two broad categories based on the extent to which tissue water potentials are kept stable despite changes in 


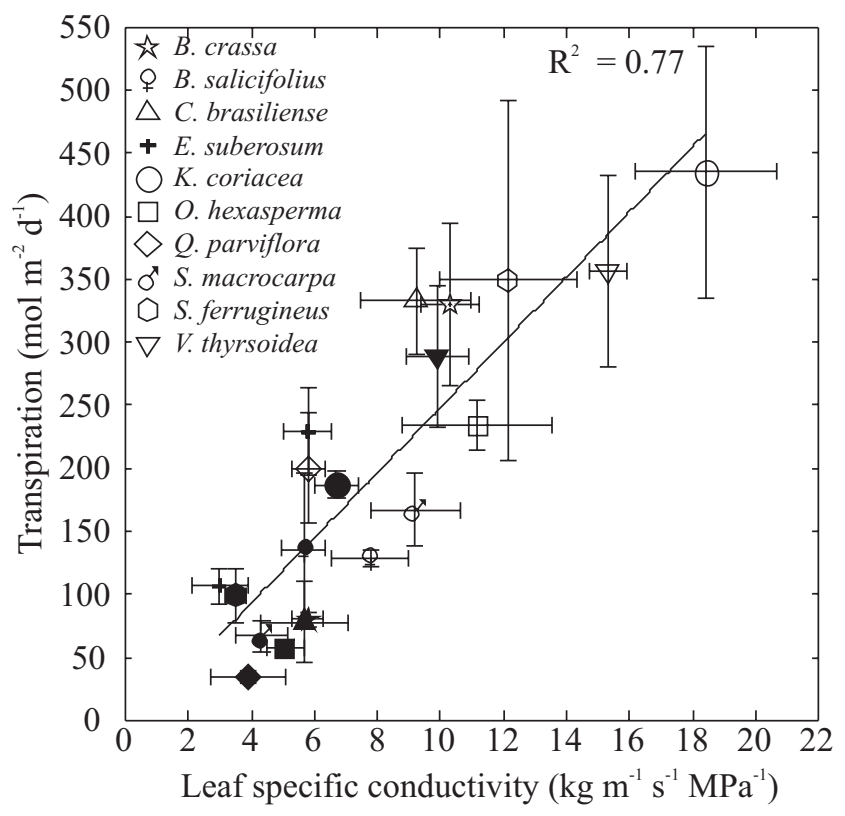

Figure 6. Total daily transpiration per unit leaf area in relation to leaf-specific hydraulic conductivity measured at the branch level during the wet season (filled symbols) and the dry season (open symbols) in ten dominant woody Cerrado species. The line is the linear regression fitted to all data $(\mathrm{y}=$ $-10.3+25.8 x ; \mathrm{P}<0.0001)$.

environmental conditions (e.g. Larcher, 1980; Frank et al., 2007). Isohydry is generally attributed to strong stomatal control of transpiration which results in similar midday $\Psi_{\mathrm{L}}$ regardless of soil moisture and D (Frank et al., 2007). Stomatal conductance of anysohydric plants, on the other hand, is less responsive to variations in D and soil moisture, allowing large seasonal fluctuations in tissue water potentials. A third mode of behavior was recently suggested by Frank and coworkers, (2007) in which soilto-leaf water potentials are maintained seasonally constant but $\Psi_{\mathrm{L}}$ fluctuates in synchrony with seasonal variations in soil water availability. Most of the mechanisms used to explain isohydric behavior are based on stomatal sensitivity to changes in atmospheric or soil moisture. However there are several other potential mechanisms that can help in maintaining seasonal constancy of plant water status, including the utilization of internal water reservoirs, changes in the total amount of gas exchange surface per plant, changes in the patterns of water uptake, and variations in the hydraulic architecture of plants.

Variation in soil water availability with depth in the

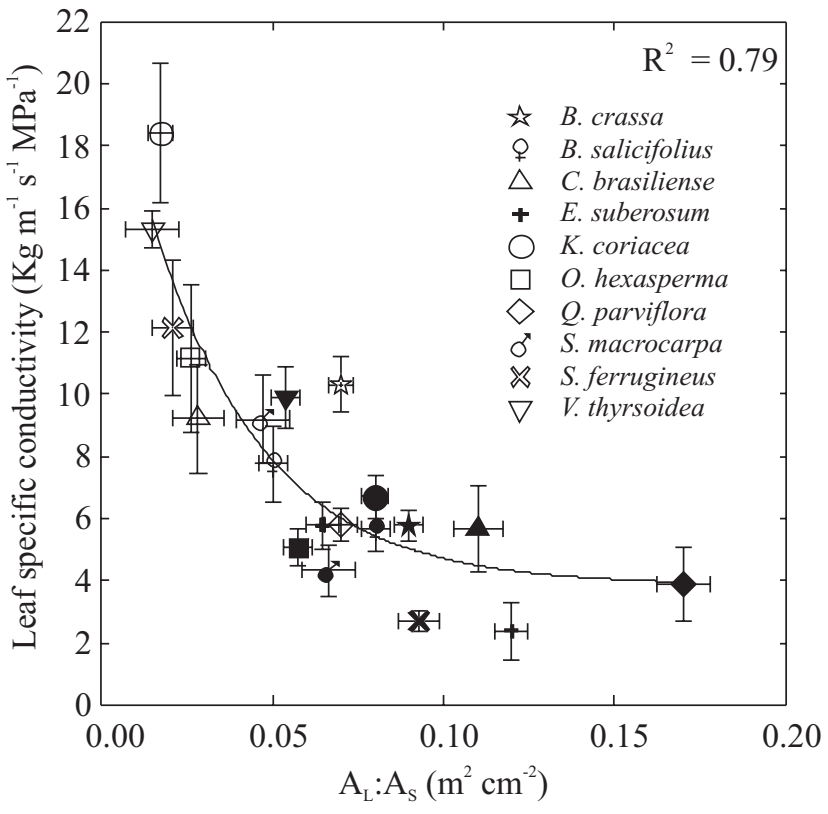

Figure 7. Leaf-specific hydraulic conductivity in relation to leaf area to sapwood area ratios $\left(A_{L}: A_{S}\right)$ measured during the wet season (filled symbols) and dry season (open symbols) for ten dominant woody Cerrado species. Each point represents the mean values \pm SE of three to five trees per species. The line is the exponential decay function fitted to the data $(\mathrm{y}=3.87 * 18.7(\exp (-30.8 \mathrm{x})) ; \mathrm{P}$ $<0.0001)$.

Brazilian Cerrado is influenced by the seasonal pattern of precipitation and by the plastic responses of root growth and physiology to variation in belowground resources. Despite a 4- to 5-month dry season, the presence of abundant moisture at depths below $2 \mathrm{~m}$ (Quesada et al., 2004, 2008) suggests that much of the annual precipitation remains unexploited by the deep roots of woody plants. Seasonal variations in water availability across the soil profile result in different patterns of water uptake by woody plants, which differ depending on their leaf phenology (deciduous, brevideciduous, evergreen) and root architecture (monomorphic in evergreen species and dimorphic in brevideciduous and deciduous species) (Scholz et al., 2008a). Adequate water supply appears to be a prerequisite for the species to maintain similar midday minimum leaf water potentials in both seasons. Consistent with the isohydric behavior of Cerrado tree species, osmotic adjustment in the leaves did not occur: the osmotic potential at zero turgor remained unchanged 


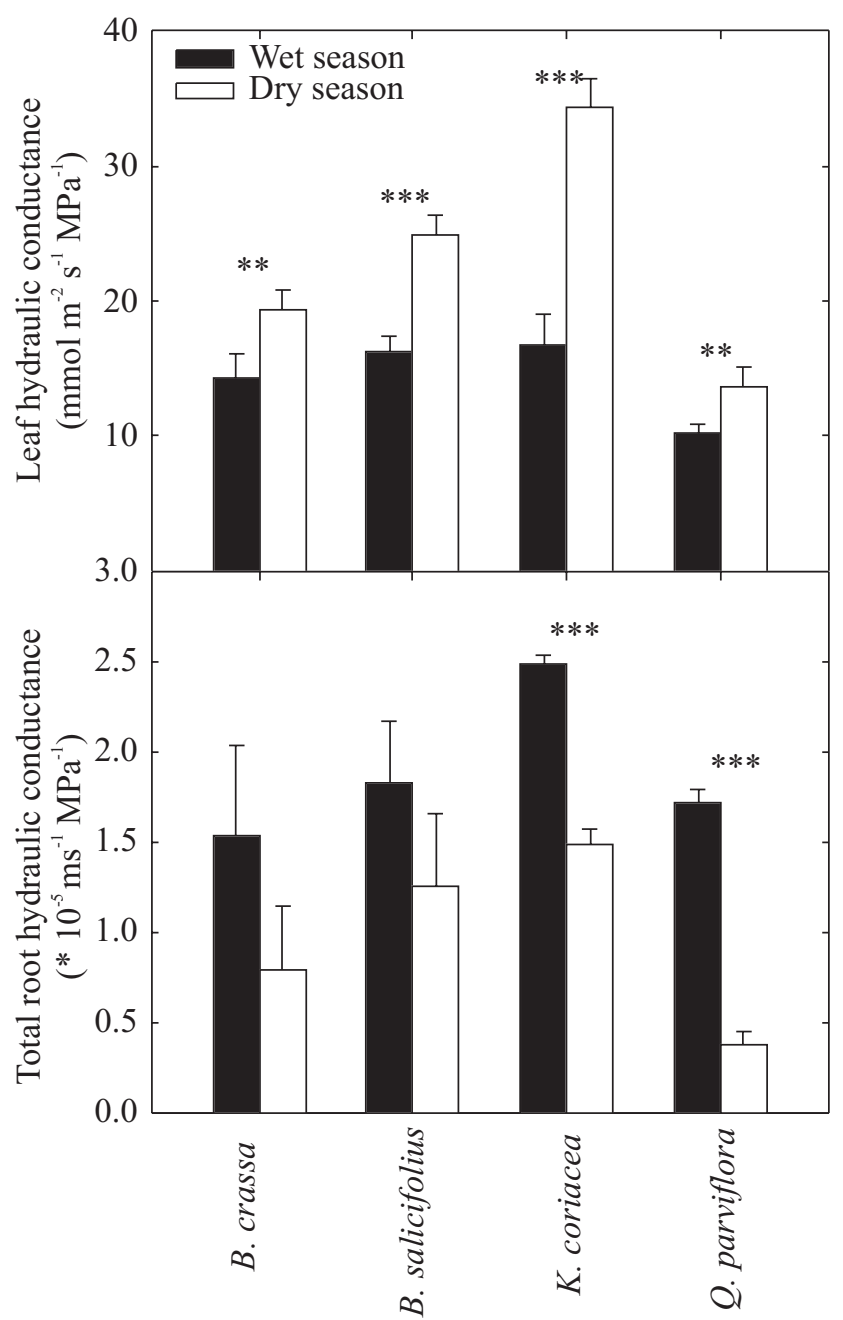

Figure 8. Leaf hydraulic conductance $\left(\mathrm{K}_{\text {Leaf }}\right)$ and total root hydraulic conductance ( $\mathrm{Lp}$ ) measured during the wet (filled bars) and dry (open bars) seasons in four dominant woody Cerrado species. Values of $\mathrm{K}_{\text {Leaf }}$ are means $+\mathrm{SE}$ of five trees per species. Values of Lp are means + SE of three to six different roots measured in different trees. Significant differences between seasons are indicated as: ** $\mathrm{P}<0.05$ and *** $\mathrm{P}<0.001$.

from wet to dry seasons and consequently, leaves of all tree species were able to maintain positive turgor pressure at midday. The contribution of superficial roots to the water economy of the trees during the dry season was very small because of limited soil water availability in the upper soil layers and also because of seasonal increases in hydraulic resistance of shallow roots (Domec et al., 2006; Scholz et al., 2008a). The occurrence of hydraulic lift in several Cerrado woody species (Scholz et

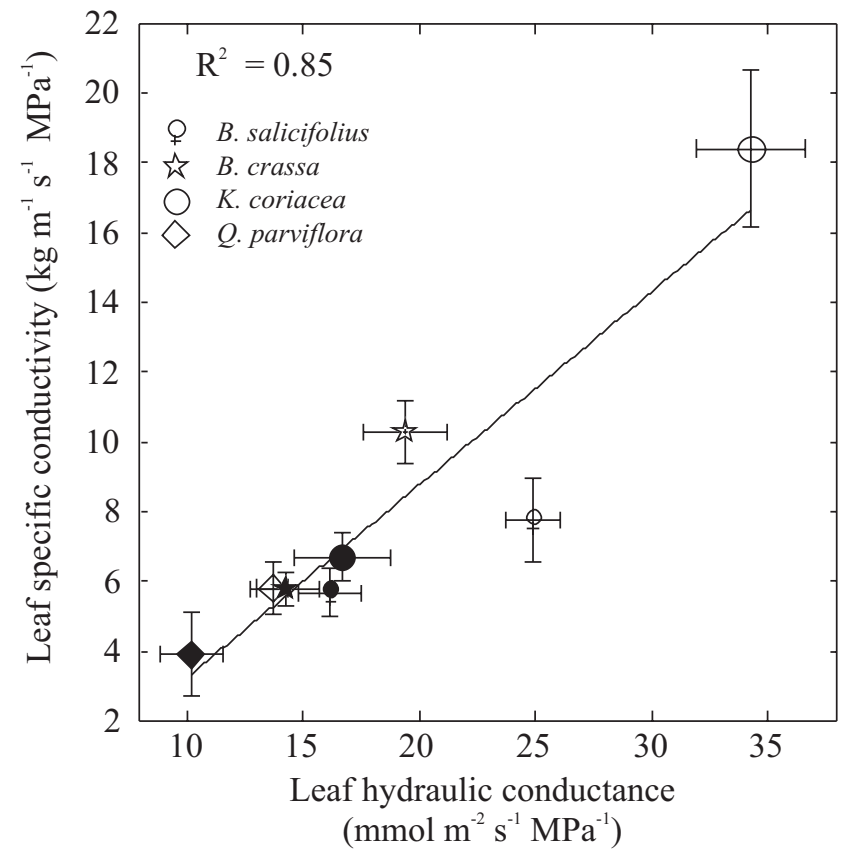

Figure 9. Relationship between leaf specific hydraulic conductivity $\left(\mathrm{K}_{\mathrm{L}}\right)$ measured at the branch level and leaf hydraulic conductance ( $\mathrm{K}_{\text {Leaf }}$ ) during wet (closed symbols) and dry (open symbols) seasons in four dominant woody species. The line is the linear regression fitted to the data $(y=-2.33+0.55 x, P<0.005)$. Each point is the mean value \pm $\mathrm{SE}$ of three to five individuals per species for $\mathrm{K}_{\mathrm{L}}$ and five individuals per species for $\mathrm{K}_{\text {Leaf }}$.

al., 2002; Moreira et al., 2003; Meinzer et al., 2004; Scholz et al., 2008a) partially mitigates but is not sufficient to prevent a substantial loss of Lp in shallow roots during the dry season (Figure 8b). Avoiding complete root rectification sensu Nobel and Sanderson (1984) may be useful for maintaining arbuscular mycorrhiza and nitrogen fixing bacteria inside the roots alive.

At the whole-plant level, total daily water loss was similar during the dry season compared to the wet season (Bucci et al., 2005). The large impact of a two-fold increase in D would have had on transpiration during the dry season was partially compensated by a decrease in stomatal conductance. Strong stomatal limitation to transpiration in response to increases in D was not sufficient to prevent transpiration per unit leaf surface area from increasing during the dry season. Therefore, additional mechanisms contributed to seasonal homeostasis of minimum $\Psi_{\mathrm{L}}$ and total daily water loss per plant. This was achieved by a substantial decrease in 
Table 2. Minimum leaf water potentials $\left(\Psi_{\mathrm{L}}\right)$, minimum sapwood water potentials $\left(\Psi_{\text {sw }}\right)$, water potential at $50 \%$ loss of maximum stem hydraulic conductivity $\left(\mathrm{P}^{50}{ }_{\text {stem }}\right)$, and 50\% loss of maximum leaf hydraulic conductance $\left(\mathrm{P}^{50}{ }_{\text {leaf }}\right)$, for six dominant Cerrado tree species. The last two parameters were estimated from leaf and stem hydraulic vulnerability curves. Values of minimum $\Psi_{\mathrm{L}}$ are means \pm SE of three to five individuals per species. Values of minimum $\Psi_{\text {sw }}$ were taken from daily course of $\Psi_{\text {swsapwood }}$ in one tree per species (Scholz et al. 2007). Values of $\mathrm{P}_{\text {stem }}^{50}$ are means \pm SE of three individuals per species.

\begin{tabular}{lcccc}
\hline & Minimum $\Psi_{\mathrm{L}}(\mathrm{MPa})$ & Minimum $\Psi_{\text {sw }}(\mathrm{MPa})$ & $\mathrm{P}_{\text {stem }}^{50}(\mathrm{MPa})$ & $\mathrm{P}_{\text {leaf }}^{50}(\mathrm{MPa})$ \\
\hline B. crassa & $-1.75 \pm 0.05$ & $-1.33 \pm 0.01$ & -1.20 \\
B. salicifolius & $-2.07 \pm 0.23$ & -0.28 & $-1.72 \pm 0.02$ & -1.53 \\
K. coriacea & $-1.56 \pm 0.05$ & -0.58 & -1.91 & -1.35 \\
Q. parviflora & $-1.70 \pm 0.09$ & -0.52 & $-1.65 \pm 0.03$ & -1.10 \\
S. ferrugineus & $-1.65 \pm 0.27$ & -0.9 & -3.35 & -1.2 \\
S. paniculatum & $-2.25 \pm 0.03$ & -1.11 & -3.20 & -0.8 \\
\hline
\end{tabular}

$A_{L}: A_{S}$ associated with shedding of leaves and a concomitant increase in $\mathrm{K}_{\mathrm{L}}$ (Figure 7 ). An additional mechanism contributing to the seasonal homeostasis was the increase in the amount of water withdrawn from the stem storages during the daytime. Utilization of water stored in stems increased by $10 \%$ during the dry season compared to the wet season (Figure 5).

Leaves constitute an important hydraulic bottleneck in the water transport pathway of plants, representing more than $30 \%$ of whole plant resistance in the root to leaf continuum (Brodribb et al., 2002; Sack et al., 2003). Leaves of Cerrado woody plants appear to be more vulnerable to embolism than their terminal stems to which they are attached (Table 2 and Hao et al., 2008). Stem xylem in Cerrado species operates far from the point of catastrophic dysfunction sensu Tyree and Sperry (1988), while leaves operate at substantially more negative leaf water potentials. Cavitation commonly occurs in leaves (e.g. Canny, 2001; LoGullo et al., 2003; Woodruff et al., 2007). Embolism repair involving the occurrence of transient pressure changes resulting from diurnal variations in the amount of osmotically active solutes inside cells surrounding leaf vascular bundles, has been documented for petioles of Cerrado trees (Bucci et al., 2003). On the other hand, embolism formation and refilling is probably of limited significance for Cerrado woody plant stems. Compared to stems, diurnal refilling in leaves may be less energetically costly and may involve simpler mechanisms (Bucci et al., 2003; Brodribb and Holbrook, 2004). Consequently, a large safety margin between minimum $\Psi$ and $\mathrm{P}^{50}$ s, will be required for stems to avoid the need of embolism repair in xylem conduits. On the other hand, from an adaptive point of view, embolism formation and repair in the leaf lamina may be a means of amplifying the evaporative demand signal to the stomata in order to expedite a stomatal response (Brodribb and Holbrook, 2004).

Leaf hydraulic conductance and $\mathrm{K}_{\mathrm{L}}$, estimates of leaf and stem water transport efficiency, respectively, increase in a coordinated manner during the dry season. Hydraulic efficiency increases in the same proportion in stem and leaves, from the wet to dry seasons (Figure 9). This hydraulic adjustment of stems and leaves during the least favorable period for metabolic and physiological activities in Cerrado plants should improve the delivery of water to the leaf cells and may contribute to insure the isohydric behavior of Cerrado trees. Increases in water transport efficiency of stems can be, at least partially, explained by a reduction in the leaf surface distal to terminal stem segments during the dry season. The mechanisms that could explain the enhancement of leaf hydraulic conductance during the dry season is not known, however the ontogenetic stage in leaf development (e.g. newly expanding and fully mature leaves) may have an influence on the movement of water within leaves (Brodribb and Holbrook, 2005).

\section{CONCLUSIONS}

Adjustments in hydraulic architecture and water relations traits of Cerrado trees during the dry season prevented increased water deficits and insured homeostasis in minimum $\Psi_{\mathrm{L}}$ and total daily water loss per plant. The isohydric behavior of Cerrado trees was the result of strong stomatal control of evaporative losses, a decrease 
in total leaf surface area per tree, an increase in $\mathrm{K}_{\text {Leaf }}$ and $\mathrm{K}_{\mathrm{L}}$ and an increase in the amount of water withdrawn from internal stem storage during the dry season. Daily repair of cavitated vessels in leaves, which appears to be less costly than in stems, is apparently necessary to insure adequate delivery of water to leaf tissues on a long term basis. All of these processes are of importance for maintaining $\Psi_{\mathrm{L}}$ above critical thresholds, which probably reduces the rate of embolism formation in stems and helps to avoid turgor loss in leaf tissues, and consequently insure continuous exogenous carbon fixation and transport of photo assimilates to plant parts that are actively growing.

Acknowledgements: This work was supported by grants from the National Science Foundation (USA) (grant \# 0296174 and grant \# 0322051), Inter-American Institute for Global Change Research, Conselho Nacional de Desenvolvimento Cientifico e Tecnologico (CNPq) and PRONEX (Brazil). We thank the Reserva Ecologica do IBGE for logistic support.

\section{REFERENCES}

Borchert R (1994) Water storage in soil or tree stems determines phenology and distribution of tropical dry forest trees. Ecology 75:1437-1449.

Brodribb TJ, Holbrook NM, Gutierrez MV (2002) Hydraulic and photosynthetic coordination in seasonally dry tropical forest trees. Plant Cell Environ 25:1435-1444.

Brodribb TJ, Holbrook NM (2003) Stomatal closure during leaf dehydration, correlation with other leaf physiological traits. Plant Physiol. 132:2166-2173.

Brodribb TJ, Holbrook NM (2004) Stomatal protection against hydraulic failure: a comparison of coexisting ferns and angiosperms. New Phytol. 162:663-670.

Brodribb TJ, Holbrook NM (2005) Leaf physiology does not predict leaf habitat; examples from tropical dry forest. Trees 19:290-295.

Bucci SJ, Scholz FG, Goldstein G, Meinzer FC (2003) Dynamic diurnal changes in hydraulic specific conductivity in petiole of two savanna tree species: identifying Factors and mechanisms contributing to the refilling of embolized vessels. Plant Cell Environ. 26:1633-1645.

Bucci SJ, Scholz FG, Goldstein G, Meinzer FC, Hinojosa
JA, Hoffmann WA, Franco AC (2004a) Processes preventing nocturnal equilibration between leaf and soil water potential in tropical savanna woody species. Tree Physiol. 24:1119-1127.

Bucci SJ, Goldstein G, Meinzer FC, Scholz FG, Franco AC, Bustamante M (2004b) Functional convergence in hydraulic architecture and water relations of tropical savanna trees: from leaf to whole plant. Tree Physiol. 24:891-899.

Bucci SJ, Goldstein G, Meinzer FC, Franco AC, Campanello P, Scholz FG (2005) Mechanisms contributing to seasonal homeostasis of minimum leaf water potential and predawn disequilibrium between soil and plants in Neotropical savanna trees. Trees 19:296-304.

Bucci SJ, Scholz FG, Goldstein G, Meinzer FC, Franco AC, Campanello PI, Villalobos-Vega R, Bustamante M, Miralles-Wilhelm F (2006) Nutrient availability constrains the hydraulic architecture and water relations of savanna trees. Plant Cell Environ. 29:21532167.

Bucci SJ, Scholz FG, Goldstein G, Hoffmann WA, Meinzer FC, Franco AC, Giambelluca T, Miralles-Wilhelm F (2008) Controls on stand transpiration and soil water utilization along a tree density gradient in a Neotropical Savanna. Agric. For. Meteorol. 148:839849.

Canny M (2001) Embolism and refilling in the maize leaf lamina and the role of the protoxylem lacuna. Am. J. Bot. 88:47-51.

Castro LHR, Kauffman J (1998) Ecosystem structure in the Brazilian Cerrado: a vegetation gradient of aboveground biomass, root mass and consumption by fire. J. Trop. Ecol. 14:263-283.

Damascos MA, Prado CHBA, Ronquim CC (2005) Bud Composition, Branching Patterns and Leaf Phenology in Cerrado Woody Species. Ann. Bot. 96:1075-1084.

Domec JC, Scholz FG, Bucci SJ, Meinzer FC, Goldstein G, Villalobos-Vega R (2006) Diurnal and seasonal variation in root xylem embolism in neotropical savanna woody species: impact on stomatal control of plant water status. Plant Cell Environ. 29:26-35.

Franco AC (1998) Seasonal patterns of gas exchange, water relations and growth of Roupala montana, an evergreen species. Plant Ecol. 136:69-76.

Franco AC, Bustamante M, Caldas LS, Goldstein G, 
Meinzer FC, Kozovits AR, Rundel P, Coradin VTR (2005) Leaf functional traits of Neotropical savanna trees in relation to seasonal water deficit. Trees 19:326335.

Frank PJ, Drake PL, Froend RH (2007) Anisohydric but isohydrodynamic: seasonally constant plant water potential gradient explained by a stomatal control mechanism incorporating variable plant hydraulic conductance. Plant Cell Environ. 30:19-30.

Furley PA, Ratter JA (1988) Soil resources and plant communities of the central Brazilian Cerrado and their development. J. Biogeogr. 15: 97-108.

Goldstein G, Andrade JL, Meinzer FC, Holbrook NM, Cavalier J, Jackson P, Celis A (1998) Stem water storage and diurnal patterns of water use in tropical forest canopy trees. Plant Cell Environ. 21:397-406.

Goldstein G, Meinzer FC, Bucci SJ, Scholz FG, Franco AC, Hoffmann WA (2008) Water economy of Neotropical savanna trees: some paradigms revisited. Tree Physiol. 28:395-404.

Gouveia GP (1998) Phenology of cerrado and gallery forest communities in central Brazil. Revista Arvore 22:443-450.

Granier A (1985) Une nouvelle méthode pour la mesure du flux de séve brute dans le tronc des arbres. Ann. Sci. For. 42:193-200.

Granier A (1987) Evaluation of transpiration in a Douglas fir stands by means of sap flow measurements. Tree Physiol. 3:309-320.

Hao G, Hoffmann WA, Scholz FG, Bucci SJ, Meinzer FC, Franco AC, Cao K-F, Goldstein G (2008). Stem and leaf hydraulics of congeneric tree species from adjacent tropical savanna and forest ecosystems. Oecologia 155:405-415.

Hoffmann WA, da Silva ER, Machado GC, Bucci SJ, Scholz FG, Goldstein G, Meinzer FC (2005) Seasonal leaf dynamics across a tree density gradient in a Brazilian savanna. Oecologia 145:307-316.

Larcher W (1980) Physiological Plant Ecology, 2nd edn, Springer-Verlag, Berlin.

Lenza E, Klink CA (2006) Comportamento fenologico de especies lenhosas em um cerrado sentido restrito de Brasilia, DF. Rev. Bras. Bot. 29:627-638.

Lo Gullo MA, Nardini A, Trifilò P, Salleo S (2003) Changes in leaf hydraulic and stomatal conductance following drought stress and irrigation in Ceratonia siliqua
(Carob tree). Physiol. Plant. 117:186-194.

Marquis RJ, Morais HC, Diniz IR (2002) Interactions among cerrado plants and their herbivores: unique or typical? In: Oliveira OS, Marquis RJ (eds) The cerrados of Brazil: ecology and natural history of a neotropical savanna. pp.306-328, Columbia University Press, New York.

Meinzer FC, Goldstein G, Franco AC, Bustamante M, Igler E, Jackson P, Caldas L, Rundel PW (1999) Atmospheric and hydraulic limitations on transpiration in Brazilian Cerrado woody species. Funct. Ecol. 13:273-282.

Meinzer FC, Brooks JR, Bucci SJ, Goldstein G, Scholz FG, Warren JM (2004) Converging patterns of uptake and hydraulic redistribution of soil water in contrasting woody vegetation types. Tree Physiol. 24:919-928.

Moreira MZ, Scholz FG, Bucci SJ, Sternberg LS, Goldstein G, Meinzer FC, Franco AC (2003) Hydraulic lift in a Neotropical savanna. Funct. Ecol. 17:573-581.

Nobel PS, Sanderson J (1984) Rectifier-like activities of roots of two desert succulents. J Exp. Bot. 35:727-737.

Nobel PS, Schulte PJ, North GB (1990) Water influx characteristics and hydraulic conductivity for roots of Agave deserti Engelm. J. Exp. Bot. 41:409-415.

Prado CHBA, Wenhiu Z, Rojas MHC, Souza GM (2004) Seasonal leaf gas exchange and water potential in a woody cerrado species community. Braz. J. Plant Physiol. 16:7-16.

Quesada CA, Miranda AC, Hodnett MG, Santos AJB, Miranda HS, Breyer LM (2004) Seasonal and depth variation of soil moisture in a burned open savanna (campo sujo) in central Brazil. Ecol. Applic. 14:533-541. Quesada CA, Hodnett MG, Breyer LM, Santos AJB, Andrade S, Miranda HS, Miranda C, Lloyd J (2008) Seasonal variations in soil water in two woodland savannas of central Brazil with different fire history. Tree Physiol. 28:405-415.

Ratter J A, Furley PA, Montgomery R F, Gifford D R (1978) Observations on forests of 14 some mesotrophic soils in Central Brazil. Rev. Bras. Bot. 1:47-58.

Rivera G, Elliott S, Caldas LS, Nicolossi G, Coradin VTR, Borchert R (2002) Increasing day-length induces spring flushing of tropical dry forest trees in the absence of rain. Trees 16:445-456.

Sack I, Cowan PD, Jaikumar N, Holbrook NM (2003) The 'hydrology' of leaves: coordination of structure and function in temperate woody species. Plant Cell 
Environ. 26:1343-1356.

Saraceno MI (2006) Efeitos da fertilizacao a longo prazo no metabolismo fotossintetico, nas caracteristicas foliares e no crescimento em arvores do cerrado. Brazil Universidade de Brasilia. Master thesis.

Sarmiento G (1983) The savannas of tropical America. In: Tropical savannas. In: Bouliere F (ed.), Ecosystem of the World/Tropical savannas, pp.245-248. Elsevier Scientific Pub. New York.

Sarmiento G, Goldstein G, Meinzer F (1985) Adaptive strategies of woody species in neotropical savannas. Biol. Rev. 60:315-355.

Scholz FG, Bucci SJ, Goldstein G, Meinzer FC, Franco AC (2002) Hydraulic redistribution of soil water by Neotropical savanna trees. Tree Physiol. 22:603-612.

Scholz FG, Bucci SJ, Goldstein G, Meinzer FC, Franco AC, Miralles-Welheim F (2006) Removal of nutrient limitations by long-term fertilization decreases nocturnal water loss in savanna trees. Tree Physiol 27:551-559.

Scholz FG, Bucci SG, Goldstein G, Meinzer FC, Franco AC, Miralles-Wilhelm F (2007) Biophysical properties and functional significance of stem water storage tissues in Neotropical savanna trees. Plant Cell Environ. 30:236-248.

Scholz FG, Bucci SJ, Goldstein G, Moreira MZ, Meinzer FC, Domec J-C, Villalobos Vega R, Franco AC, MirallesWilhelm, F (2008a) Biophysical and life history determinants of hydraulic lift in Neotropical savanna trees. Funct. Ecol. 22:773-786.

Scholz FG, Bucci SJ, Goldstein G, Meinzer FC, Franco AC, Miralles-Wilhelm, F (2008b) Temporal dynamics of stem expansion and contraction in savanna trees: withdrawal and recharge of stored water. Tree Physiol. 28:469-480.

Simioni G, Gignoux J, Le Roux X, Appe R, Benest D (2004) Spatial and temporal variations in leaf area index, specific leaf area and leaf nitrogen of two co-occurring savanna tree species. Tree Physiol. 24:205-216.

Sperry JS, Tyree MT (1988) Mechanism of water stressinduced xylem embolism. Plant Physiol 88:581-587.

Tardieu F, Simonneau T (1998) Variability among species of stomatal control under fluctuating soil water status and evaporative demand: modeling isohydric and anisohydric behaviors. J. Exp. Bot. 49:419-432.

Turner NC, Jones MN (1980) Turgor maintenance by osmotic adjustment: a review and evaluation. In:Turner NC, Kramer PJ (eds.), Adaptation of plant to water and high temperature stress, pp.87-104. Wiley \& Sons, New York.

Tyree MT, Hammel HT (1972) The measurement of the turgor pressure and water relations of plants by the pressure bomb technique. J. Exp. Bot. 23:267-282.

Tyree MT, Sperry JS (1988) Do woody plants operate near the point of catastrophic xylem dysfunction caused by dynamic water stress? Answers from a model. Plant Physiol. 88:574-580.

Tyree MT, Sperry JS (1989) Vulnerability of xylem to cavitation and embolism. Ann. Rev. Plant Mol. Bio. 40:19-48.

Woodruff DR, McCulloh KA, Warren JM, Meinzer FC, Lachenbruch B (2007) Impacts of tree height on leaf hydraulic architecture and stomatal control in Douglas-fir. Plant Cell Environ 30:559-569. 